\title{
Bartonella alsatica sp. nov., a new Bartonella species isolated from the blood of wild rabbits
}

\author{
Rémy Heller, ${ }^{1}$ Maryline Kubina, ${ }^{1}$ Philippe Mariet, ${ }^{1}$ Philippe Riegel, ${ }^{1}$ \\ Gilles Delacour, ${ }^{2}$ Christoph Dehio, ${ }^{3}$ François Lamarque, ${ }^{2}$ Rick Kasten, ${ }^{4}$ \\ Henri-Jean Boulouis, ${ }^{5}$ Henri Monteil, ${ }^{1}$ Bruno Chomel $^{3}$ and Yves Piémont ${ }^{1}$
}

Author for correspondence: Rémy Heller. Tel: +33 388211970. Fax: + 33388251113.
e-mail: yves.piemont@medecine.u-strasbg.fr

1 Institut de Bactériologie de la Faculté de Médecine, Université Louis-Pasteur, Hôpitaux Universitaires de Strasbourg, 3 rue Koeberlé, 67000 Strasbourg, France

2 Office National de la Chasse, Gerstheim, France

3 Max-Planck-Institut für Biologie, Tübingen, Germany

4 Department of Population Health and Reproduction, School of Veterinary Medicine, University of California, Davis, CA, USA

5 Departement de Microbiologie, Ecole Nationale Vétérinaire d'Alfort, Maisons-Alfort, France

\begin{abstract}
Bartonella species are considered as emerging human pathogens, with at least six different species pathogenic or possibly pathogenic for humans. However, little is known about Bartonella distribution, species polymorphism and pathogenicity in mammalian species. The objective of this work was to determine the presence, the frequency and the distribution of Bartonella species in wild rabbits (Oryctolagus cuniculus) caught in warrens in Alsace, France. Humans may come into contact with wild rabbits when hunting, especially when they are picked up with bare hands and at time of evisceration. Of 30 blood samples collected and cultured from wild rabbits, nine $(30 \%)$ were positive for organisms morphologically similar to Bartonella spp. The bacteria appeared as small, fastidious, aerobic, oxidase-negative, Gram-negative rods which could be localized within erythrocytes. Their biochemical properties were similar to those of the genus Bartonella. The sequence of the 165 rRNA gene obtained from the rabbit isolates was highly related to the sequences of the different Bartonella species (97.8-99.3\% similarity). The high DNA hybridization rate (81-90\% similarity) between the three strains isolated from rabbit blood confirmed that they belong to the same bacterial species. Hybridization values, obtained with the nuclease-TCA method, when testing type strains of recognized Bartonella species (9-14\% similarity), support the creation of a new species for the rabbit isolates. The name Bartonella alsatica is proposed for these strains isolated from the blood of wild rabbits. The type strain is IBS $382^{\top}$ (= CIP 105477').
\end{abstract}

Keywords: Bartonella, Bartonella alsatica, wild rabbit, Oryctolagus cuniculus, zoonoses

\section{INTRODUCTION}

The bacterial genus Bartonella consisted of one species until 1993 and includes at present 11 species, formerly classified in the genera Bartonella, Grahamella, Rickettsia or Rochalimaea (Birtles et al., 1995; Brenner et al., 1993). Nine reference strains isolated from humans or small mammals are available from international bacterial collections and include the following species: Bartonella bacilliformis, Bartonella clarridgeiae, Bartonella doshiae, Bartonella elizabethae, Bartonella grahamii, Bartonella henselae, Bartonella quintana, Bar-

The EMBL/GenBank accession number for the 165 rRNA gene sequence of strain IBS $382^{\top}$ is AJ002139. tonella taylorii and Bartonella vinsonii. The two other species, Bartonella talpae and Bartonella peromysci, initially classified in the genus Grahamella (Birtles et al., 1995), were isolated from small mammals, but no reference strains are available and their 16S rRNA gene sequence is also unknown.

Six of the 11 Bartonella species described can produce pathogenic disorders in humans (Bass et al., 1997a, b; Kordick et al., 1997; Schwartzman, 1996) and therefore Bartonella species are considered as emerging human pathogens. $B$. henselae and B. clarridgeiae were isolated from cats and the diseases caused by these bacteria are considered as zoonoses; $B$. vinsonii was isolated from voles and a subspecies, $B$. vinsonii subsp. berkhoffi, was isolated from healthy dogs and from a 
dog with an endocarditis (Kordick et al., 1996). However, no animal reservoir has been identified for the three other species pathogenic to humans: $B$. bacilliformis, $B$. elizabethae and $B$. quintana. Furthermore, little is known about the distribution, species polymorphism and pathogenicity of Bartonella species among various mammalian species.

The objective of this work was to explore potential reservoirs of Bartonella species in wild mammals. We therefore tested a population of wild rabbits captured in warrens in the Alsace region, France, to determine the presence, the frequency and the distribution of Bartonella species in this population.

\section{METHODS}

Reference strains and accession numbers for the 16S RNA gene sequences. B. grahamii NCTC $12860^{\mathrm{T}}$ (accession no. Z31349), B. taylorii NCTC $12861^{\mathrm{T}}$ (Z31350), B. doshiae NCTC $12862^{\mathrm{T}}\left(\right.$ Z31351) and B. vinsonii ATCC VR-152 ${ }^{\mathrm{T}}$ (L01259) were kindly provided by R. Birtles (Bristol, UK). $B$. henselae ATCC 49882 ${ }^{\mathrm{T}}$ (M73229) and $B$. elizabethae ATCC $49927^{\mathrm{T}}$ (L01260) were purchased from the American Type Culture Collection (ATCC; Manassas, VA, USA).

The EMBL/GenBank accession numbers for the other 16S rRNA gene sequences of the different Bartonella species used for sequence comparison are: B. bacilliformis, M65249; B. clarridgeiae (ATCC $51734^{\mathrm{T}}$ ), X8920; B. henselae (type BA-TF), Z11684; B. quintana (VR-358 ${ }^{\mathrm{T}}$ ), M11927.

Rabbit population. The wild rabbits (Oryctolagus cuniculus) enrolled in the study were caught between October 1996 and January 1997 in a warren in a protected natural zone near the Rhine river in the eastern part of France. Four different episodes of capture were organized. The first three episodes of capture took place in a limited warren of $1 \mathrm{~km}^{2}$ ( 24 rabbits caught); the fourth episode occurred over the same surface range in a warren located $60 \mathrm{~km}$ north from the first place (six rabbits caught).

Thirty wild rabbits were caught with the help of a trained ferret and were transferred in capture boxes. They were lightly tranquillized by intramuscular injection of a blend of tiletamine and zolazepam. Approximately $1 \mathrm{ml}$ rabbit blood was collected from an external ear vein and placed into a Pediatric Isolator 1.5 tube (Wampole Laboratories) for haemolysis. One drop of blood of each animal was smeared on a glass slide.

The rabbits were ear-marked with a numeric identification system and then released, except for four of them, which were sent to the Veterinary Departmental Services for histopathological examination.

Isolation of strains. Blood culture was performed as described previously (Heller et al., 1997). Briefly, two different media were used for primary culture: a Columbia agar base containing 5\% defibrinated rabbit blood and a Bactec Peds Plus (Becton Dickinson Diagnostic Instrument Systems) liquid medium supplemented with $500 \mu \mathrm{l}$ Bacto Fildes enrichment (Difco). Incubation of the plates was performed at $35^{\circ} \mathrm{C}$ in a moist atmosphere containing $5 \% \mathrm{CO}_{2}$ for up to 2 months. Three randomly selected plates without any sample were incubated in parallel with the inoculated blood agar plates of the same batch as a sterility test. The Bactec
Peds Plus vials were tested for $\mathrm{CO}_{2}$ production each week for up to 6 months. The $\mathrm{CO}_{2}$-positive Bactec Peds Plus vials were tested for the presence of bacteria by light microscopic examination as described below. Positive broth medium was subcultured on rabbit-blood Columbia agar medium.

Light microscopic examination. Direct examination of the animal blood smears was performed after staining with the May-Grünwald-Giemsa stain. The stained blood smears were examined by two independent readers through an oilimmersion objective at a magnification of $\times 1000$. If no infected erythrocytes were observed after a 5 min examination, the smear was considered negative.

The cultured micro-organisms were visualized by acridine orange staining and with the enhanced Gram stain by using a counterstain of Kinyoun carbol fuchsin at a $1 / 20$ dilution (Larson et al., 1994) at a magnification of $\times 1000$.

Electron microscopy. Bacteria grown on solid medium were prepared for electron microscopy as previously described by Fusseneger et al. (1996). Briefly, bacteria were suspended in PBS ( $0.145 \mathrm{M} \mathrm{NaCl} ; 0.15 \mathrm{M}$ sodium phosphate), spread on a water surface and absorbed to Formvar-coated nickel grids. The grids were stained in $1 \%$ uranyl acetate and airdried. The samples were viewed under a Zeiss M109 electron microscope at $80 \mathrm{kV}$.

Biochemical analysis. The following biochemical tests were performed with diagnostic tablets (Rosco Diagnostica): Voges-Proskauer reaction, tributyrin hydrolysis, pyrazinamidase and trypsin-like activity. The MicroScan Rapid Anaerobe Panel (Baxter Diagnostics) was used to test the activity of preformed bacterial enzymes. These biochemical tests correspond to those used to identify biochemical characteristics described for other Bartonella species (Birtles et al., 1995; Brenner et al., 1993).

Amplification of the 16S rRNA gene. Amplification of the $16 \mathrm{~S}$ rRNA gene was performed as previously described (Heller et al., 1997). Briefly, DNA was extracted from several colonies (3-10 colonies). In vitro amplification of a 1500 bp DNA fragment was performed with two 16S rRNA gene eubacterial universal primers: P8 (5' AGAGTTTGATCCTGGCTCAG 3') and Pc1544 (5' AAGGAGGTGATCCAGCCGCA $3^{\prime}$ ). Standard procedures to prevent sample DNA contamination were undertaken (Kwok \& Higuchi, 1989). Negative controls were included in each experiment to check for the absence of cross-contamination between samples and between previously amplified products and field samples.

Purification of the amplified product and DNA sequencing. The amplified DNA fragment was purified by phenol extraction and 2-propanol precipitation (Brow, 1990). Sequencing was performed with a Thermo Sequenase fluorescent labelled primer cycle sequencing kit with 7-deazadGTP (Amersham Life Science) according to the manufacturer's instructions. Sequence was obtained with an ALF DNA Sequencer (Pharmacia Biotech) according to the manufacturer's instructions. Sequencing of the complete 16S rRNA gene fragment was performed on the coding and the complementary strands, for the type strain and two other strains, with four couples of primers: P8 and Pc535 ( $5^{\prime}$ GTATTACCGCGGCTGCTGGCAC 3'), P515 (5' GTGCCAGCAGCCGCGGTAAKAC 3') and Pc804 (5' GACTACCAGGGTATCTAATCC 3'), P784 (5' GGATTAGATACCCTGGTAGTC 3') and Pcl198 (5' ACTTGACGTTATCCCCACCTTCC 3'), P1174 (5' GAGGAAGGTGGGGATGACGTC 3') and Pc1544. All primers were $5^{\prime}$ 
labelled with fluorescein isothiocyanate. For the other isolates, only sequencing of the region of the first 430 bases of the 16S rRNA gene was performed by using the internal primer Pc535. This region corresponds to the most informative region when compared with other known $16 \mathrm{~S}$ rRNA gene sequences.

$16 S$ rDNA sequence analysis. The sequences obtained were compared with the homologous sequences of other bacteria including all Bartonella spp. contained in the EMBL/ GenBank database and the sequences of the other Bartonella isolates obtained from rabbits. The sequences were aligned by using the CLUSTAL method (Higgins \& Sharp, 1988) with DNAStar software.

DNA-DNA hybridization. Colonies were harvested from blood agar plates and DNA was extracted as previously described (Riegel et al., 1994). Hybridization between the labelled DNA and the fragmented-DNA preparation was carried out at $58^{\circ} \mathrm{C}$ for $16 \mathrm{~h}$ in $0.42 \mathrm{M} \mathrm{NaCl}$ by the nuclease-TCA method (Grimont et al., 1980; Riegel et al., 1994). This corresponds to stringent conditions.

Determination of DNA base composition. The $\mathrm{G}+\mathrm{C}$ content of DNA was determined by capillary electrophoresis as described previously (Riegel et al., 1995).

\section{RESULTS}

\section{Rabbit population}

A total of 30 wild rabbits were sampled. Two of the four rabbits which were sent to the Veterinary Departmental Services for histopathological examination were positive in culture for Bartonella sp. All four rabbits looked healthy and no particular histopathological abnormalities were observed, especially in relation to Bartonella infection.

\section{Culture and identification}

Of the 30 wild rabbits tested, nine $(30 \%)$ were culturepositive for Bartonella spp. Eight (33\%) strains were isolated from the rabbits captured in the first warren and one $(17 \%)$ was isolated from the rabbits captured in the second warren. The colonies were seen on blood agar after $10 \mathrm{~d}$ post-inoculation and culture was detectable in liquid medium after 4 weeks. For six of the nine positive rabbits, culture was obtained both on solid and liquid media, while the three remaining isolates were cultured only from liquid medium on primary isolation. On blood agar, the number of c.f.u. $\mathrm{ml}^{-1}$ ranged from 100 to 2500 with a mean of 866 c.f.u. $\mathrm{ml}^{-1}$.

The colonies which grew after $10 \mathrm{~d}$ on blood agar appeared as small, white, smooth, regular colonies (diameter of about $1 \mathrm{~mm}$ ). When the plates were incubated for a longer time period, the colonies became bigger, turned brown and were adherent to the medium. Microscopic examination after enhanced Gram staining showed small Gram-negative rods. Electron microscopic examination showed small bacilli $(0 \cdot 5-0.8 \mu \mathrm{m}$ wide and $1-2 \mu \mathrm{m}$ long) with polar pili

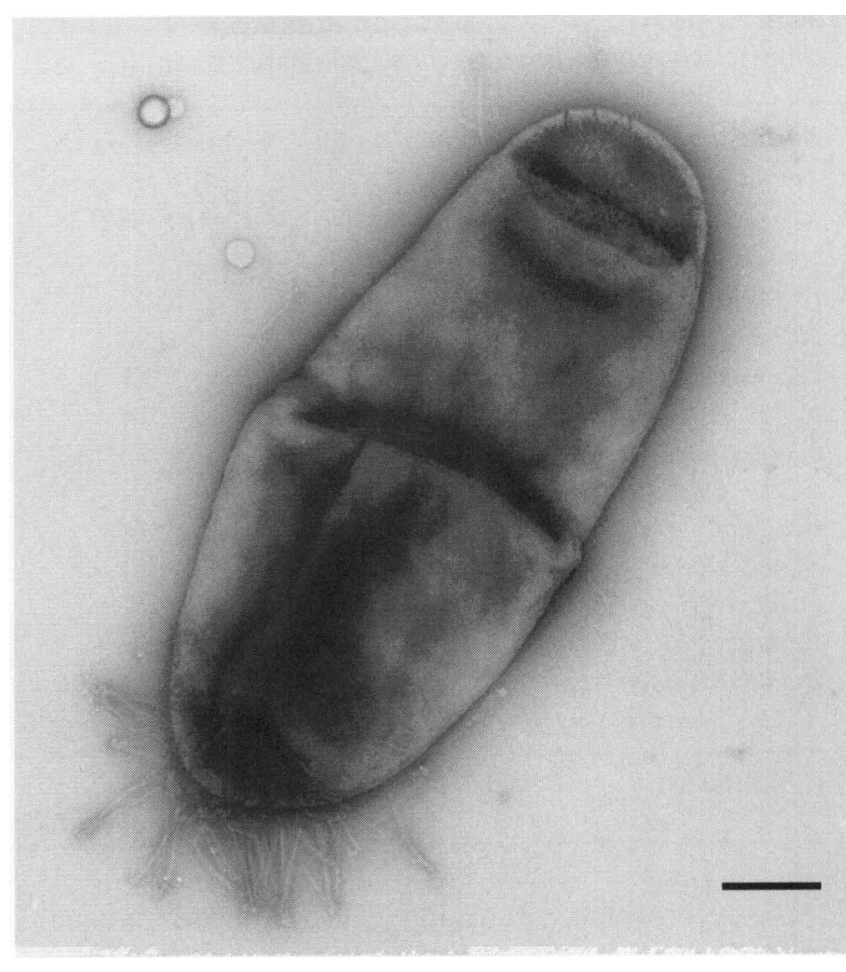

Fig. 1. Negative staining of strain IBS $382^{\top}$ showing the presence of polar pili. Bar, $0.25 \mu \mathrm{m}$.

but without flagella (Fig. 1). The three isolates tested (IBS $382^{\mathrm{T}}$, IBS 379 and IBS 460) were catalasenegative, exhibited a negative Voges-Proskauer reaction, had negative pyrazinamidase and urease activities and did not produce acid from trehalose. They did not hydrolyse bis- $p$-nitrophenyl phosphate or $p$ nitrophenyl $N$-acetyl- $\beta$-D-glucosaminide, and had amino acid arylamidase activity with the following amino acids: leucine, methionine, lysine (alkaline as well as acid), glycine, proline, arginine and tryptophan. They had glycylglycylarylamidase and trypsin-like activity but no pyrrolidonylarylamidase activity.

Sequencing of the complete 16S rRNA gene was performed for the three different isolates previously examined (isolates IBS $382^{\mathrm{T}}$, IBS 379 and IBS 460). The three sequences obtained were identical to each another but differed from those previously known for other Bartonella species. The closest 16S rRNA gene sequence was the one of $B$. vinsonii, which had 10 different bases $(0.7 \%$ difference), and the most distant was $B$. bacilliformis, with 30 different bases $(2 \cdot 2 \%$ difference). Sequencing of the six other isolates was performed only for the first 430 bases and the six sequences were strictly identical to those obtained for the three isolates whose $16 \mathrm{~S}$ rRNA gene was entirely sequenced. Half of the nucleotide differences between the sequences of the rabbit isolates and the sequences of the other Bartonella species are localized in the first 430 bases of the $16 \mathrm{~S}$ rRNA gene. The $G+C$ content of 
Table 1. DNA-DNA hybridization and 16S rRNA gene similarity between Bartonella species and strain IBS $382^{\top}$

\begin{tabular}{|lcc|}
\hline Bartonella strain & $\begin{array}{c}\text { Similarity (\%) for } \\
\text { the 16S rRNA } \\
\text { gene }\end{array}$ & $\begin{array}{c}\text { Hybridization (\%) } \\
\text { with strain } \\
\text { IBS 382 }\end{array}$ \\
\hline IBS 382 & & \\
IBS 379 & $100 \cdot 0$ & 100 \\
IBS 460 & $100 \cdot 0$ & 90 \\
B. vinsonii & $100 \cdot 0$ & 81 \\
B. doshiae & $99 \cdot 3$ & 14 \\
B. grahamii & $99 \cdot 1$ & 12 \\
B. taylorii & $99 \cdot 0$ & 9 \\
B. henselae & $98 \cdot 9$ & 14 \\
B. elizabethae & $98 \cdot 9$ & 12 \\
B. quintana & $98 \cdot 5$ & 9 \\
B. clarridgeiae & $98 \cdot 2$ & $\mathrm{NT}$ \\
B. bacilliformis & $98 \cdot 0$ & $\mathrm{NT}$ \\
\hline
\end{tabular}

NT, Not tested.

DNA, determined by capillary electrophoresis, was 37 mol $\%$.

\section{Blood smear examination}

No blood smear from any of the 30 wild rabbits was found positive. Nevertheless, we injected the isolate IBS $382^{\mathrm{T}}$ experimentally to three laboratory rabbits and observed bacteria in their erythrocytes, as determined by blood smear examination. The number of bacteria observed in each infected erythrocyte ranged between 10 and 40 organisms, but very few erythrocytes were infected $\left(<10^{-4}\right)$. The bacteraemia in experimentally infected rabbits persisted for 2-3 months.

\section{DNA-DNA hybridization}

The DNA of isolate IBS $382^{\mathrm{T}}$ was labelled and tested by DNA-DNA hybridization against unlabelled DNA of two other rabbit isolates (IBS 379 and IBS 460) and against unlabelled DNA of type strains of phylogenetically related Bartonella species (less than 1.5\% difference in the $16 \mathrm{~S}$ rRNA gene sequence). The results are shown in Table 1 in parallel with the 16S rRNA gene sequence homology values. Isolates IBS 379 and IBS 460 showed more than $80 \%$ DNA-DNA similarity with isolate IBS $382^{\mathrm{T}}$ whereas low relatedness (less than $15 \%$ ) was found between isolate IBS $382^{\mathrm{T}}$ and type strains of Bartonella species tested, thus confirming that the three wild rabbit isolates represent a single species distinct from other Bartonella species.

\section{DISCUSSION}

The bacteria isolated from the blood of wild rabbits grew slowly and required enriched media. They appeared as small, fastidious, aerobic, oxidase-negative,
Gram-negative rods, which could be localized within erythrocytes. They grew best on blood-enriched media in an atmosphere containing $5 \% \mathrm{CO}_{2}$. Their biochemical properties were similar to those of other species of the genus Bartonella. Their 16S rRNA sequence was also highly related to the $16 \mathrm{~S}$ rRNA sequence of Bartonella, since the closest one was the sequence of $B$. vinsonii with $99 \cdot 3 \%$ homology and the most divergent one, among the genus Bartonella, was the sequence of $B$. bacilliformis with $97.9 \%$ homology. The high hybridization rate of the three isolates $(81-90 \%)$ tested by DNA-DNA hybridization confirmed that they belong to the same bacterial species. Only species with a $16 \mathrm{~S}$ rRNA gene sequence similarity over $98.5 \%$ were tested for DNA-DNA hybridization; this threshold was chosen because in the genus Bartonella the intraspecies differences in the 16S rRNA gene are known to be very low (Birtles \& Raoult, 1996), so slight differences can be considered to be significant. The low rate of hybridization of the rabbit isolate IBS $382^{\mathrm{T}}$ with the other type strains of Bartonella species tested demonstrates that this isolate belongs to a new Bartonella species. Our hybridization values obtained between the type strains of Bartonella species were low in comparison to the hybridization values obtained by other workers. These results are due to the hybridization methods used. In contrast to most of the previous studies on Bartonella where the hydroxyapatite method was used (Birtles et al., 1995; Daly et al., 1993; Welch et al., 1992), we used in this study the nuclease-TCA method, which is known to give lower hybridization rates (Grimont et al., 1980; Riegel et al., 1994) as the experimentation is performed under more stringent conditions. Based on criteria defining a species (Wayne et al., 1987), we conclude that the corresponding strains constitute a new species within the genus Bartonella for which the name Bartonella alsatica is proposed.

For characterization of the different strains, 16S rRNA gene amplification followed by sequencing was used. This method was selected as it allows a universal characterization of tested strains, especially for unknown bacteria. Other methods using restriction enzymes such as PCR-RFLP are more useful only when the tested species are well-defined, as the results depend greatly on the restriction enzyme used.

Only one type of $16 \mathrm{~S}$ rRNA gene sequence was found for all Bartonella strains isolated from wild rabbits. In contrast, different Bartonella species may be isolated (Heller et al., 1997) from cat blood and co-infections have been observed (Gurfield et al., 1997). The two rabbit populations tested were living at a distance of approximately $60 \mathrm{~km}$ from each another, but the strains isolated from these rabbits had an identical $16 \mathrm{~S}$ rRNA gene sequence and a high DNA homology, as shown by strains IBS $382^{\mathrm{T}}$ and IBS 379 isolated from rabbits from the first area, and strain IBS 460 isolated from a rabbit captured in the second area. The blood of other small mammals (field mice or field voles) trapped in the same areas was also tested but failed to 
yield the same Bartonella species. This work reports for the first time the isolation of Bartonella from wild rabbits. Further studies need to be conducted to determine the distribution of this new Bartonella species among rabbit populations worldwide.

The fact that (i) the Bartonella species isolated from the wild rabbits was different from all the Bartonella species hitherto known, (ii) only one type of $16 \mathrm{~S}$ rRNA gene sequence could be found for the different isolates and (iii) no clinical or histopathological abnormalities could be detected strongly supports a long-term adaptation of this new bacterial species to its rabbit reservoir.

The rate of infected erythrocytes seems to be very low in natural conditions. No infected red blood cells could be observed on the wild rabbit blood smears, contrary to Kordick \& Breitschwerdt (1995), who found 2.9$6.2 \%$ infected erythrocytes in the blood of cats. However, culture of wild rabbit blood had a maximum yield of 2500 c.f.u. $\mathrm{ml}^{-1}$ in primary isolation on blood agar and three strains were isolated only from liquid media. This may explain why Bartonella species were not previously described for wild rabbits (Weinman \& Kreier, 1977).

Since we used domestic rabbit blood to make the agar medium on which Bartonella was cultivated, systematic controls were performed to test the sterility of the plates. For each batch, three randomly selected plates without any sample were incubated in parallel with the inoculated blood agar plates, to assess that the Bartonella growing on the inoculated plates did not originate from the rabbit blood incorporated in the agar medium. None of the control plates tested yielded Bartonella cultures. Moreover, for each batch, $0.2 \mathrm{ml}$ of the domestic rabbit blood used for preparing blood agar plates was also cultured in parallel on these blood agar plates, and no growth of Bartonella species was ever observed.

More than a half of the wild rabbits sampled were infested by fleas or ticks. These ectoparasites have been implicated in Bartonella transmission, especially fleas for the cats (Chomel et al., 1996; Higgins et al., 1996), and could also be implicated in the transmission of Bartonella in wild rabbits. Furthermore, infested wild rabbits could be a potential source of human contamination when hunted and skinned, as the ectoparasites could eventually bite humans. We have no evidence about whether the Bartonella species carried by these rabbits can be transmitted to humans and eventually be implicated in human pathology. However, several human cases reported as 'cat scratch disease' are not serologically related to $B$. henselae, and some cases have occurred without any cat contact history. The rate for these cases was estimated by some authors to be as high as $60 \%$ of clinical cat scratch disease cases (Dupon et al., 1996; Yoshida et al., 1996). Many Bartonella species appear to be present in our environment and should be carefully investigated. This investigation should focus on updating diagnostic tools to determine the importance of these Bartonella species in human and animal pathology.

\section{Description of Bartonella alsatica sp. nov.}

Bartonella alsatica (al.sa'ti.ca. L. adj. alsaticus from Alsace, the region in the eastern part of France near the Rhine river where the wild rabbits were trapped and where the strains were isolated and identified).

Colonies grown on blood agar appeared after $10 \mathrm{~d}$ as small, white, smooth, regular colonies (diameter of about $1 \mathrm{~mm}$ ). Electron microscopic examination showed small bacilli without flagella and with a size of approximately $1-2 \mu \mathrm{m}$ in length by $0.5-0.8 \mu \mathrm{m}$ in width. B. alsatica is a Gram-negative rod, aerobic, oxidase-negative. It grows best on blood-enriched media in a moist atmosphere containing $5 \% \mathrm{CO}_{2}$. The three strains tested were all catalase-negative, produced negative Voges-Proskauer reaction, had negative pyrazinamidase and urease activities and did not acidify trehalose. They did not hydrolyse bis- $p$-nitrophenyl phosphate or $p$-nitrophenyl $N$-acetyl- $\beta$-D-glucosaminide, and had amino acid arylamidase activity with the following amino acids: leucine, methionine, lysine (alkaline as well as acid), glycine, proline, arginine and tryptophan. They had glycylglycylarylamidase and trypsin-like activity but no pyrrolidonylarylamidase activity. The new species is distinguished from the other Bartonella species by its 16S rRNA gene sequence and by the whole DNA hybridization. The type strain is IBS $382^{\mathrm{T}}$, which was isolated from the blood of a wild rabbit and deposited in the Collection de l'Institut Pasteur under the number CIP $105477^{\mathrm{T}}$. Its $\mathrm{G}+\mathrm{C}$ DNA content is $37 \mathrm{~mol} \%$ (as determined by the capillary electrophoresis method). Its 16S rRNA gene sequence has been deposited in the EMBL database under the number AJ002139.

\section{ACKNOWLEDGEMENTS}

We thank S. Niedergang, C. Fritsch, B. Pichler-Brand and C. Tosch for their technical assistance. We also thank the Office National de la Chasse team who helped us to catch the wild rabbits.

\section{REFERENCES}

Bass, J., Vincent, J. \& Person, D. (1997a). The expanding spectrum of Bartonella infections. I. Bartonellosis and trench fever. Pediatr Infect Dis $J$ 16, 2-10.

Bass, J., Vincent, J. \& Person, D. (1997b). The expanding spectrum of Bartonella infections. II. Cat scratch disease. Pediatr Infect Dis $J$ 16, 163-179.

Birtles, R. J. \& Raoult, D. (1996). Comparison of partial citrate synthase gene $(\mathrm{glt} A)$ sequences for phylogenetic analysis of Bartonella species. Int J Syst Bacteriol 46, 891-897.

Birtles, R. J., Harrison, T. G., Saunders, N. A. \& Molyneux, D. H. (1995). Proposals to unify the genera Grahamella and Bartonella, with descriptions of Bartonella talpae comb. nov., Bartonella peromysci comb. nov., and three new species, Bartonella grahamii sp. nov., Bartonella taylorii sp. nov., and Bartonella doshiae sp. nov. Int J Syst Bacteriol 45, 1-8. 
Brenner, D. J., O'Connor, S. P., Winkler, H. H. \& Steigerwalt, A. G. (1993). Proposals to unify the genera Bartonella and Rochalimaea, with descriptions of Bartonella quintana comb. nov., Bartonella vinsonii comb. nov., Bartonella henselae comb. nov., and Bartonella elizabethae comb. nov., and to remove the family Bartonellaceae from the order Rickettsiales. Int J Syst Bacteriol 43, 777-786.

Brow, M. A. (1990). Sequencing with Taq DNA polymerase. In PCR Protocols: a Guide to Methods and Application, pp. 189-196. Edited by M. A. Innis, D. H. Gelfand, J. J. Sninsky \& T. J. White. San Diego, CA: Academic Press.

Chomel, B. B., Kasten, R. W., Floydhawkins, K. \& 7 other authors (1996). Experimental transmission of Bartonella henselae by the cat flea. J Clin Microbiol 34, 1952-1956.

Daly, J. S., Worthington, M. G., Brenner, D. J. \& 7 other authors (1993). Rochalimaea elizabethae sp. nov. isolated from a patient with endocarditis. J Clin Microbiol 31, 872-881.

Dupon, M., Delarclause, A. M. S., Brouqui, P., Drancourt, M., Raoult, D., Demascarel, A. \& Lacut, J. Y. (1996). Evaluation of serological response to Bartonella henselae, Bartonella quintana and Afipia felis antigens in 64 patients with suspected cat scratch disease. Scand J Infect Dis 28, 361-366.

Fusseneger, M., Kahrs, A. F., Facius, D. \& Meyer, T. F. (1996). Tetrapac (tpc), a novel genotype of Neisseria gonorrhoeae affecting epithelial cell invasion, natural transformation competence and cell separation. Mol Microbiol 19, 1357-1372.

Grimont, P. A. D., Popoff, M. Y., Grimont, F., Coynault, C. \& Lemelin, M. (1980). Reproducibility and correlation study of three deoxyribonucleic acid hybridization procedures. Curr Microbiol 4, 325-330.

Gurfield, N., Boulouis, H. J., Chomel, B., Heller, R., Larsen, R. W., Yamamoto, K. \& Piémont, Y. (1997). Co-infection by Bartonella clarridgeiae and Bartonella henselae and different Bartonella henselae strains in domestic cats. J Clin Microbiol 35, 21102113.

Heller, R., Artois, M., Xemar, V., De Briel, D., Gehin, H., Jaulhac, B., Monteil, H. \& Piemont, Y. (1997). Prevalence of Bartonella henselae and Bartonella clarridgeiae in stray cats. $J$ Clin Microbiol 35, 1327-1331.

Higgins, D. G. \& Sharp, P. M. (1988). CLUSTAL: a package for performing multiple sequence alignment on a microcomputer. Gene 73, 237-244.

Higgins, J. A., Radulovic, S., Jaworski, D. C. \& Azad, A. F. (1996). Acquisition of the cat scratch disease agent Bartonella henselae by cat fleas (Siphonaptera:Pulicidae). J Med Entomol 33, 490-495.

Kordick, D. L. \& Breitschwerdt, E. B. (1995). Intraerythrocytic presence of Bartonella henselae. J Clin Microbiol 33, 1655-1656.

Kordick, D. L., Swaminathan, B., Greene, C. E. \& 11 other authors (1996). Bartonella vinsonii subsp. berkhoffi i subsp. nov., isolated from dogs; Bartonella vinsonii subsp vinsonii; and emended description of Bartonella vinsonii. Int $J$ Syst Bacteriol 46, 704-709.

Kordick, D., Hilyard, E., Hadfield, T., Wilson, K., Steigerwalt, A., Brenner, D. \& Breitschwerdt, E. (1997). Bartonella clarridgeiae, a newly recognized zoonotic pathogen causing inoculation papules, fever, and lymphadenopathy (cat scratch disease). $J$ Clin Microbiol 35, 1813-1818.

Kwok, S. \& Higuchi, R. (1989). Avoiding false positives with PCR. Nature 339, 237-238.

Larson, A. M., Dougherty, M. J., Nowowiejski, D. J., Welch, D. F., Matar, G. M., Swaminathan, B. \& Coyle, M. B. (1994). Detection of Bartonella (Rochalimaea) quintana by routine acridine orange staining of broth blood cultures. J Clin Microbiol 32, 1492-1496.

Riegel, P., de Briel, D., Prevost, G., Jehl, F. \& Monteil, H. (1994). Genomic diversity among Corynebacterium jeikeium strains and comparison with biochemical characteristics and antimicrobial susceptibilities. J Clin Microbiol 32, 1860-1865.

Riegel, P., Ruimy, R., de Briel, D., Prévost, G., Jehl, F., Christen, R. \& Monteil, H. (1995). Corynebacterium seminale $\mathrm{sp}$. nov. a species associated with genital infections in male patients. $J$ Clin Microbiol 32, 2244-2249.

Schwartzman, W. (1996). Bartonella (Rochalimaea) infections: beyond cat scratch. Annu Rev Med 47, 355-364.

Wayne, L. G., Brenner, D. J., Colwell, R. R. \& 9 other authors (1987). International Committee on Systematic Bacteriology. Report of the ad hoc committee on reconciliation of approaches to bacterial systematics. Int J Syst Bacteriol 37, 463-464.

Weinman, D. \& Kreier, J. P. (1977). Bartonella and Grahamella. In Parasitic Protozoa, pp. 197-233. Edited by J. P. Kreier. London: Academic Press.

Welch, D. F., Pickett, D. A., Slater, L. N., Steigerwalt, A.G. \& Brenner, D. J. (1992). Rochalimaea henselae sp. nov., a cause of septicemia, bacillary angiomatosis, and parenchymal bacillary peliosis. J Clin Microbiol 30, 275-280.

Yoshida, H., Kusaba, N., Omachi, K. \& 8 other authors (1996). Serological study of Bartonella henselae in cat scratch disease in Japan. Microbiol Immunol 40, 671-673. 